Article

\title{
Occurrence of Acute Oesophageal Necrosis (Black Oesophagus) in a Single Tertiary Centre
}

\author{
Orlando Davide, Carabotti Marilia, Ruggeri Maurizio, Esposito Gianluca $\mathbb{D}$,

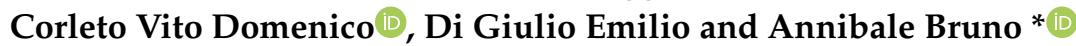

Medical-Surgical Department of Clinical Sciences and Translational Medicine, Sant'Andrea Hospital, University Sapienza, 00189 Rome, Italy; davidegiuseppeorlando@hotmail.it (O.D.); mariliacarabotti@gmail.com (C.M.); maurizio.ruggeri@gmail.com (R.M.); gle.esposito@gmail.com (E.G.); vito.corleto@gmail.com (C.V.D.); edigiulio52@gmail.com (D.G.E.)

* Correspondence: bruno.annibale@uniroma1.it; Tel.: +39-06-33775695

Received: 3 September 2019; Accepted: 22 September 2019; Published: 24 September 2019

\begin{abstract}
Acute oesophageal necrosis $(\mathrm{AON})$ is a rare condition characterised by the endoscopic finding of diffuse, circumferential, black mucosal pigmentation of the oesophagus, which typically stops at the gastro-oesophageal junction. This observational study aimed to assess the occurrence, clinical characteristics and outcomes of $\mathrm{AON}$ in a consecutive endoscopic cohort in a single tertiary university centre. A retrospective analysis of endoscopic data of upper gastrointestinal endoscopy (UGE) was carried out from 2008 to 2018. Out of 25,970 UGE, 16 patients $(0.06 \%)$ had AON; 75.0\% were men with a median age of 75 years. Almost all patients underwent diagnosis during emergency UGE performed for gastrointestinal bleeding, but one patient was diagnosed during elective UGE for persistent vomiting and diarrhoea. All patients reported one or more pre-existing comorbidities and concomitant acute events. Two patients had AON as the first presentation of Zollinger-Ellison syndrome (ZES). One patient developed an oesophageal stenosis, and another patient presented a relapse of AON. Mortality was $50 \%$, but no patient died as a direct consequence of AON. AON is a rare cause of gastrointestinal bleeding diagnosed mainly during emergency UGE. Our study showed that ZES might manifest with this critical presentation, and endoscopists must be aware of this evidence.
\end{abstract}

Keywords: black oesophagus; acute oesophageal necrosis; gastrointestinal bleeding; upper gastrointestinal endoscopy; oesophageal stenosis; Zollinger-Ellison syndrome

\section{Introduction}

Acute oesophageal necrosis (AON), so-called black oesophagus, is a rare condition characterised by the endoscopic finding of diffuse, often circumferential, black mucosal pigmentation of the oesophagus, which typically stops at the gastro-oesophageal junction [1].

Epidemiological data of $\mathrm{AON}$ are scant, and the prevalence of this condition is supposed to be low. In fact, large retrospective series reported that the estimated incidence ranged from $0.01 \%[2,3]$ to $0.28 \%[4]$.

AON is more frequent in elderly men with medical comorbidities, often presenting with upper gastrointestinal bleeding, ranging from haematemesis, coffee ground emesis, and melena $[1,5,6]$. Prognosis is poor, with an overall mortality of $32 \%$ usually related to the underlying comorbidities and an estimated specific mortality of $6 \%[1,5,6]$.

The AON aetiology is likely multifactorial. It has been hypothesized that AON arises from a combination of oesophageal hypoperfusion with consequent ischaemia, impaired mucosal defence barrier and injury related to reflux of gastric contents [2]. To date, there has been no specific therapeutic 
protocol for this condition, and medical management has been directed to treat the coexisting underlying illness.

The aim of this observational retrospective study was to assess the occurrence, clinical characteristics and outcomes of $\mathrm{AON}$ in a consecutive endoscopic cohort over an 11-year period in a tertiary university centre.

\section{Materials and Methods}

A retrospective analysis of endoscopic data of elective and emergency upper gastrointestinal endoscopy (UGE) was carried out from January 2008 to December 2018 in a single tertiary university centre. Our electronic endoscopic database (Endobase Olympus) was searched using the following keywords: "oesophagus", "black", "necrosis", and "necrotic".

The criterion for the diagnosis of AON was the presence of circumferential black appearance of oesophageal mucosa that stops abruptly at the gastro-oesophageal junction [1-4,7]. Patients with other causes of oesophageal injury, such as caustic ingestion, severe esophagitis, malignancies and other benign disorders, were excluded. Gastric and duodenal endoscopic findings were assessed in all AON cases. Duodenal involvement-associated AON was considered in the presence of erosions, ulcers or necrotic aspects of the mucosa of the bulb and of the second portion.

Clinical records, including demographic, laboratory findings, radiological exams, pharmacological history, medical treatment, and outcome, were collected; each patient comorbidity was reported and expressed using the Charlson Index [8]. Anaemia was considered severe, moderate or mild when haemoglobin levels were $\leq 12-13,8-10$, and $\leq 8 \mathrm{~g} / \mathrm{dL}$, respectively [9].

Data were expressed as the percentage (\%) of the total, or the median and interquartile range IQR or a range. The study was approved by the local ethics committee.

\section{Results}

According to the electronic search, $88(0.34 \%)$ patients out of 25,970 were found in our endoscopic database. All endoscopic reports were individually checked to carefully ascertain the AON diagnostic criteria. Of the 88 patients, 72 were excluded, and 16 patients were diagnosed with AON (Figure 1). Almost all AON diagnoses were performed during emergency UGE $[15 / 2515(0.60 \%)]$, and only one case of AON was found during an elective exam [1/23,455 (0.004\%)].

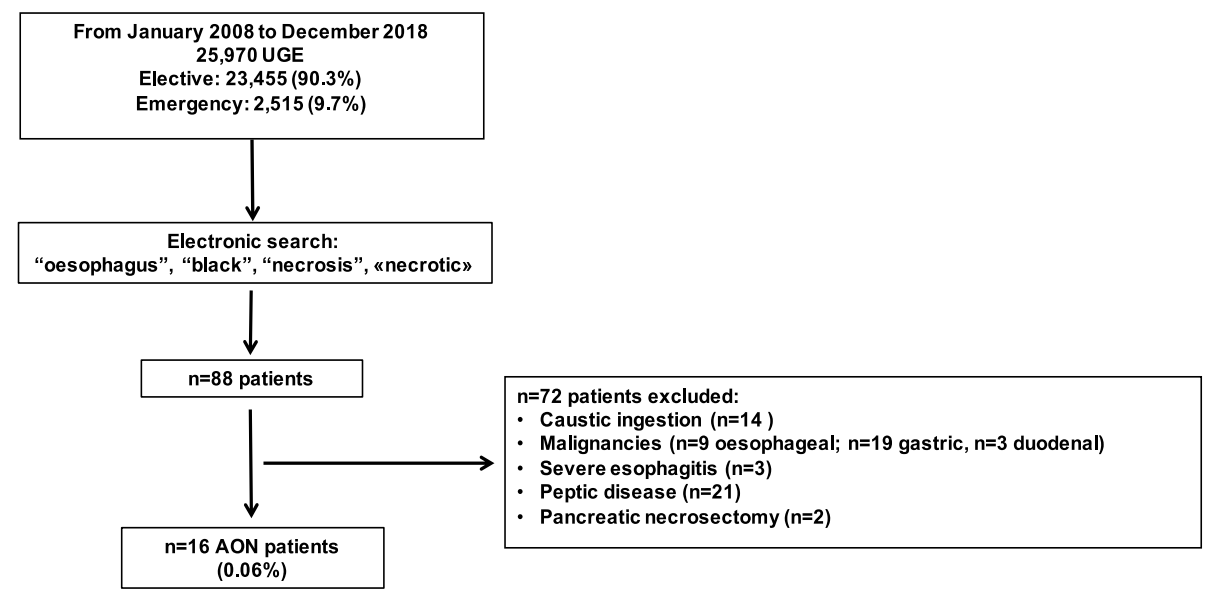

Figure 1. Flow-chart of the study. UGE, upper gastrointestinal endoscopy; AON, acute oesophageal necrosis.

\subsection{Demographics, Clinical Presentation and Comorbidities}

Of the 16 patients, $12(75.0 \%)$ were men with a median age of 75 years (range $47-89)$.

The reasons for hospitalization were as follows: nine patients with upper gastrointestinal bleeding $(56.2 \%)$, two patients with abdominal pain $(12.5 \%)$, one patient with fever, one with persistent vomiting and diarrhoea, one with acute renal failure, one with traumatic fracture and one with dysphagia. 
The only case of AON observed during an elective endoscopy was admitted for persistent vomiting and diarrhoea.

Clinical and laboratory data at the time of endoscopy, with indications for UGE, are reported in Table 1.

Table 1. Clinical, laboratory data, and indications for UGE in AON patients $(n=16)$.

\begin{tabular}{ll}
\hline Physical Examination & \\
\hline Hypotension (lower than 100/60 mmHg) & $3 / 16(18.7 \%)$ \\
Tachycardia (>100 bpm) & $3 / 16(18.7 \%)$ \\
Hypoxemia (SpO2 < 60) & $1 / 16(6.2 \%)$ \\
Laboratory Analysis & \\
Leukocytosis (WBC > 10.000/ $\mu \mathrm{L})$ & $13 / 16(81.2 \%)$ \\
Increased C-reactive protein $(>0.5$ & $12 / 16(75 \%)$ \\
mg/dL) & $11 / 16(68.7 \%)$ \\
Anaemia & $6 / 11(54.5 \%)$ \\
Mild & $2 / 11(18.2 \%)$ \\
Moderate & $3 / 11(27.3 \%)$ \\
Severe & $13 / 16(81.2 \%)$ \\
Increased glycaemia $(>100 \mathrm{mg} / \mathrm{dL})$ & $12 / 16(75 \%)$ \\
Increased creatinine $(>1.5 \mathrm{mg} / \mathrm{dL})$ & $10 / 11(90.9 \%)$ \\
Hypoalbuminemia $(<3 \mathrm{~g} / \mathrm{dL}) *$ & \\
Indications for UGE & $13 / 16(81.2 \%)$ \\
Upper GI bleeding & $1 / 16(6.2 \%)$ \\
Vomiting & $1 / 16(6.2 \%)$ \\
Worsening of anaemia & $1 / 16(6.2 \%)$ \\
Dysphagia &
\end{tabular}

$\mathrm{Bpm}=$ beats per minute; $\mathrm{UGE}=$ upper gastrointestinal endoscopy; GI = gastrointestinal; $\mathrm{WBC}=$ White blood cell.

* Albumin dosage was available in 11 patients.

Haemodynamic instability (hypotension and tachycardia) was present in three patients, one of which also presented hypoxemia. Physical examination of the other 13 AON patients was unremarkable. Thirteen patients $(81.2 \%)$ had leukocytosis [median white blood cell count $14.800 / \mu \mathrm{L}$ $(\mathrm{IQR}=13.000-18.700)]$, and 12 patients $(75 \%)$ had elevated C-reactive protein [median $2.9 \mathrm{mg} / \mathrm{dL}$ $(\mathrm{IQR}=2-12.3)]$. Eleven patients $(68.7 \%)$ had anaemia, and twelve $(75 \%)$ had an elevated creatinine level [median $1.3 \mathrm{mg} / \mathrm{dL}(\mathrm{IQR}=1.9-5.4)$ ], but a known history of chronic renal failure was reported only in five patients. Thirteen patients (81.2\%) showed hyperglycaemia levels [median $185 \mathrm{mg} / \mathrm{dL}$ $(\mathrm{IQR}=113-278)]$, but only seven of them were diabetic. Ten patients had low levels of albumin [median $2.8 \mathrm{~g} / \mathrm{dL}(\mathrm{IQR}=2.1-3.6)$ ].

All patients reported one or more concomitant pre-existing comorbidities: seven patients $(43.7 \%)$ had diabetes, six (37.5\%) had arterial hypertension, five (31.2\%) had chronic renal failure, three (18.7\%) had chronic ischaemic heart disease, three (18.7\%) cerebral vascular disease and two (12.5\%) had active malignancies (pancreatic adenocarcinoma). Concomitant acute events at the time of AON diagnosis were reported in almost all patients: seven (43.7\%) had pneumonia, six (37.5\%) had acute renal failure, two (12.5\%) had Clostridium difficile colitis, one had acute myocardial infarction and one developed $A O N$ a few days after orthopaedic surgery. Two patients had AON as the first presentation of Zollinger-Ellison syndrome (ZES). Pre-existing and concomitant comorbidities in each patient are fully reported in Table 2. 
Table 2. Demographic characteristics, comorbidities, endoscopic findings and outcome of patients with AON.

\begin{tabular}{|c|c|c|c|c|c|c|c|c|c|}
\hline $\begin{array}{c}\text { Year of } \\
\text { Diagnosis }\end{array}$ & Age & Gender & Chronic Comorbidities & $\begin{array}{c}\text { Acute } \\
\text { Concomitant } \\
\text { Comorbidities }\end{array}$ & $\begin{array}{c}\text { Charlson } \\
\text { Index }\end{array}$ & $\begin{array}{l}\text { Oesophageal } \\
\text { Necrosis } \\
\text { Extension }\end{array}$ & $\begin{array}{l}\text { Duodenal } \\
\text { Involvement }\end{array}$ & $\begin{array}{l}\text { Other } \\
\text { Endoscopic } \\
\text { Findings }\end{array}$ & Outcome \\
\hline 2008 & 74 & M & $\begin{array}{l}\text { Chronic renal failure, diabetes, chronic } \\
\text { ischaemic heart disease and cerebral } \\
\text { vascular disease }\end{array}$ & $\begin{array}{l}\text { Acute renal } \\
\text { failure }\end{array}$ & 5 & I-II-III & $\begin{array}{l}\text { Duodenal's } \\
\text { ulcers }\end{array}$ & - & $\begin{array}{l}\text { Discharged without } \\
\text { follow-up endoscopy }\end{array}$ \\
\hline 2009 & 76 & $\mathrm{M}$ & Cerebral vascular disease & $\begin{array}{l}\text { Pneumonia and } \\
\text { sepsis }\end{array}$ & 3 & I-II-III & $\begin{array}{l}\text { Duodenal's } \\
\text { ulcers }\end{array}$ & - & Death from septic shock \\
\hline 2010 & 80 & $\mathrm{M}$ & Chronic renal failure & $\begin{array}{l}\text { Pneumonia and } \\
\text { acute renal failure }\end{array}$ & 5 & I-II-III & $\begin{array}{l}\text { Bulb's } \\
\text { necrosis }\end{array}$ & $\begin{array}{l}\text { Necrotic } \\
\text { aspect of } \\
\text { pylorus }\end{array}$ & Death from multi-organ failure \\
\hline 2010 & 74 & $\mathrm{M}$ & $\begin{array}{l}\text { Chronic renal failure, dilatative } \\
\text { cardiomyopathy and COPD }\end{array}$ & $\begin{array}{l}\text { Acute renal } \\
\text { failure }\end{array}$ & 7 & I-II-III & - & - & Lost to follow-up \\
\hline 2012 & 47 & M & Diabetes, atrial fibrillation and psoriasis & Pneumonia & 3 & II- III & - & Hiatal hernia & Oesophageal stenosis \\
\hline 2012 & 69 & M & $\begin{array}{l}\text { Arterial hypertension, diabetes and } \\
\text { depressive syndrome }\end{array}$ & $\begin{array}{l}\text { Vertebral fracture } \\
\text { and } C D \text { colitis }\end{array}$ & 3 & III & $\begin{array}{l}\text { Duodenal's } \\
\text { ulcers }\end{array}$ & $\begin{array}{l}\text { Hiatal hernia } \\
\text { Mallory Weiss }\end{array}$ & $\begin{array}{l}\text { Discharged without } \\
\text { follow-up endoscopy }\end{array}$ \\
\hline 2014 & 81 & M & $\begin{array}{l}\text { Chronic renal failure, silicosis and } \\
\text { brachy-tachycardia syndrome }\end{array}$ & Pneumonia & 6 & I-II-III & $\begin{array}{l}\text { Duodenal's } \\
\text { ulcers }\end{array}$ & - & Death from multi-organ failure \\
\hline 2016 & 64 & $\mathrm{M}$ & IV stage pancreatic adenocarcinoma & $\begin{array}{l}\text { Recent NSAID } \\
\text { assumption }\end{array}$ & 8 & II-III & Bulb's ulcers & Hiatal hernia & Death from acute renal failure \\
\hline 2016 & 65 & $\mathrm{~F}$ & $\begin{array}{l}\text { Zollinger-Ellison syndrome } \\
\text { in metastatic NET }\end{array}$ & $\begin{array}{l}\text { Vomiting and } \\
\text { diarrhoea }\end{array}$ & 8 & I-II-III * & $\begin{array}{l}\text { Duodenal's } \\
\text { ulcers }\end{array}$ & Hiatal hernia & Remission at follow-up UGE \\
\hline 2016 & 85 & M & $\begin{array}{l}\text { Alzheimer disease, decubitus lesions and } \\
\text { atrial fibrillation }\end{array}$ & $\begin{array}{l}\text { Pneumonia and } \\
\text { CD colitis }\end{array}$ & 5 & III & $\begin{array}{l}\text { Duodenal's } \\
\text { erosions }\end{array}$ & & Death from septic shock \\
\hline 2016 & 84 & $\mathrm{~F}$ & $\begin{array}{l}\text { Zollinger-Ellison syndrome in pancreatic } \\
\text { gastrinoma, chronic ischaemic heart } \\
\text { disease and arteria hypertension }\end{array}$ & Pneumonia & 12 & III & $\begin{array}{l}\text { Duodenal's } \\
\text { ulcers }\end{array}$ & Hiatal hernia & $\begin{array}{l}\text { AON relapse } 3 \text { weeks after the } \\
\text { first episode }\end{array}$ \\
\hline 2017 & 87 & $\mathrm{~F}$ & $\begin{array}{c}\text { Pancreatic adenocarcinoma, chronic } \\
\text { ischaemic heart disease, hypertension, } \\
\text { diabetes, Parkinson disease and } \\
\text { senile dementia }\end{array}$ & $\begin{array}{l}\text { Acute renal } \\
\text { failure }\end{array}$ & 9 & III & $\begin{array}{l}\text { Duodenal's } \\
\text { erosions }\end{array}$ & Hiatal hernia & Death from acute renal failure \\
\hline 2018 & 71 & M & Diabetes & $\begin{array}{c}\text { Superficial } \\
\text { thrombophlebitis }\end{array}$ & 4 & II- III & - & - & Remission at follow-up UGE \\
\hline 2018 & 89 & M & $\begin{array}{c}\text { Hypertension, diabetes, dyslipidaemia } \\
\text { and glaucoma }\end{array}$ & Pneumonia & 5 & III & - & $\begin{array}{l}\text { Hiatal hernia } \\
\text { gastric } \\
\text { volvolus }\end{array}$ & Death from septic shock \\
\hline 2018 & 66 & M & $\begin{array}{l}\text { Charcot Marie Tooth polyneuropathy, } \\
\text { arterial hypertension and diabetes }\end{array}$ & $\begin{array}{l}\text { Acute renal } \\
\text { failure }\end{array}$ & 3 & I-II-III & $\begin{array}{l}\text { Duodenal's } \\
\text { ulcers }\end{array}$ & - & Remission at follow-up UGE \\
\hline 2018 & 77 & $\mathrm{~F}$ & $\begin{array}{c}\text { Cerebral vascular disease, Alzheimer } \\
\text { disease, arterial hypertension and chronic } \\
\text { renal failure }\end{array}$ & $\begin{array}{l}\text { NSTEMI and } \\
\text { acute on chronic } \\
\text { renal failure }\end{array}$ & 7 & II-III & $\begin{array}{l}\text { Necrotic areas } \\
\text { of II portion }\end{array}$ & - & Death from multi-organ failure \\
\hline
\end{tabular}




\subsection{Endoscopic Findings}

AON was involved the entire length of oesophagus in seven patients (43.8\%), the distal one-third in five $(31.2 \%)$ and the distal two-thirds in four $(25 \%)$ patients. Concomitant duodenal abnormalities were reported in 12 patients (75\%): eight (50\%) presented frank duodenal ulcers, two patients presented duodenal erosions, and the other two patients presented a necrotic aspect of the duodenum. Further endoscopic findings included seven cases of hiatal hernia, one case of Mallory-Weiss lesion, one case of gastric volvulus and one patient presenting necrotic aspect of the pylorus.

Endoscopic gastric and duodenal findings with respect to oesophageal necrosis extension are reported in Figure 2. Endoscopic presentation of a patient with AON is showed in Figure 3.

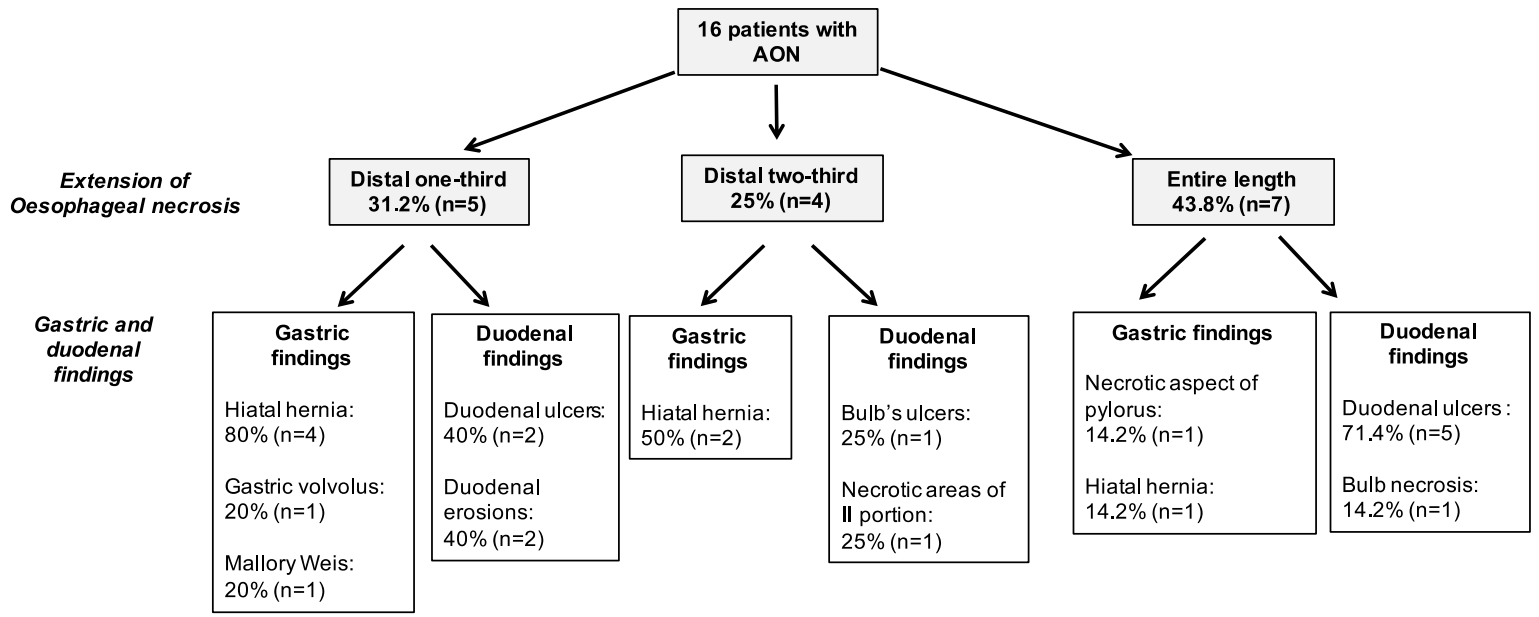

Figure 2. Endoscopic findings in acute oesophageal necrosis patients. AON, acute oesophageal necrosis.

(a)

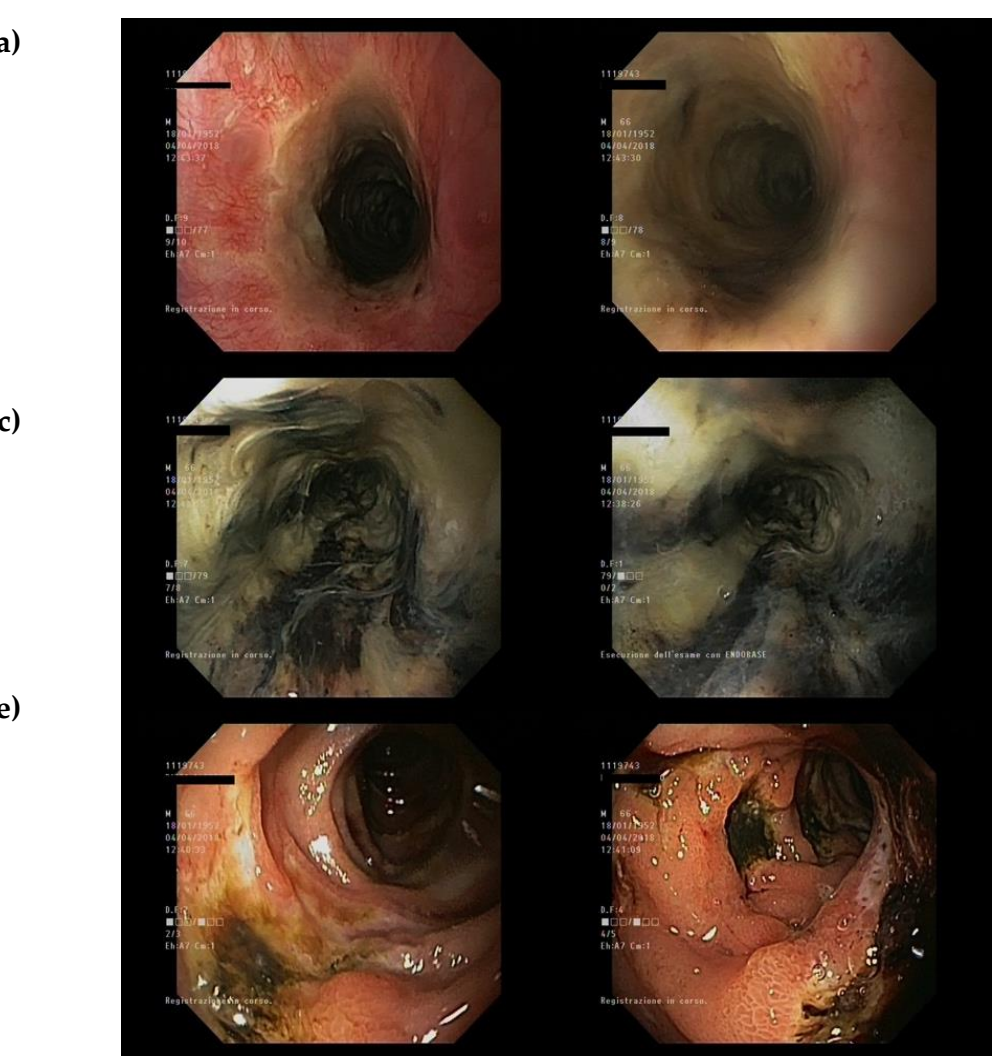

(b)

(c)

(e)

(d)

(f)

Figure 3. Endoscopic presentation of patient with AON. (a) Proximal oesophagus; (b) Proximal oesophagus; (c) Medium oesophagus; (d) Distal oesophagus; (e) Duodenal ulcers; (f) Duodenal ulcers. 


\subsection{Medical and Endoscopic Treatment}

Medical treatment for AON included intravenous proton pump inhibitors in all patients $(81.2 \%$ continuous infusion for at least $72 \mathrm{~h} ; 18.8 \%$ with twice a day intravenous administration). Nil per os and total parenteral nutrition were prescribed in $60 \%$ of patients. The majority of patients received antibiotics (73\%) with associated antimycotics (25\%). Eight patients (50\%) required 1-4 red blood cell transfusions during hospitalization and two somatostatin infusions.

Among the twelve patients with duodenal involvement, three patients required endoscopic haemostasis due to ulcer bleeding. One patient further required transcatheter angiographic embolization and surgery to treat bleeding from duodenal ulcers.

\subsection{Outcome}

None of the patients developed oesophageal perforation. Specifically, in only nine cases, contrast-enhanced computed tomography CT was performed within $24 \mathrm{~h}$ of AON diagnosis, showing oesophageal thickening in five patients and duodenal thickening in three patients.

Eight patients (50\%) died between 1-30 days of an AON event: three (37.5\%) died from multi-organ failure, three (37.5\%) died from septic shock, and two patients (25\%) died from acute renal failure. None of the patients who died from septic shock had CT signs of perforation.

At follow-up endoscopy, three patients showed AON remission, one patient developed oesophageal stenosis as an AON complication, and one patient complaining of vomiting and diarrhoea presented an AON relapse three weeks after the first episode (Figure 4). Notably, patients with AON recurrence are diagnosed with ZES.

Two patients completed uneventful hospitalization and were discharged without follow-up endoscopy. One patient was transferred to another hospital, and he was lost to follow-up.

The two patients with ZES underwent UGE twenty-eight months after the first AON episode, without showing any significant endoscopic findings.

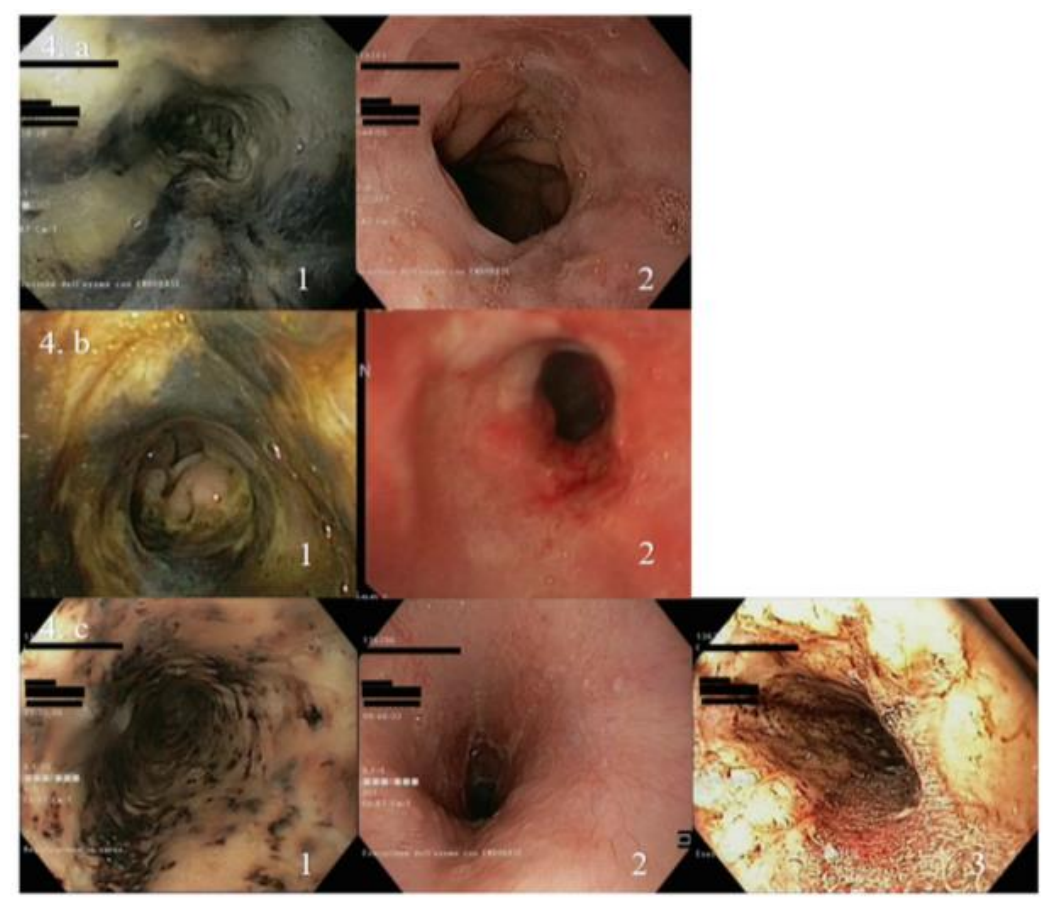

Figure 4. Endoscopic presentation of AON patients. (a) Endoscopic presentation of AON patient with remission. 1. AON at diagnosis; 2. AON remission after 51 days. (b) Endoscopic presentation of AON patient developing oesophageal stenosis. 1. AON at diagnosis; 2. Oesophageal stenosis. (c) Endoscopic presentation of patient who presented $\mathrm{AON}$ recurrence. 1. AON, endoscopic presentation at first episode; 2 . AON remission after 15 days; 3 . AON recurrence after 3 weeks. 


\section{Discussion}

This study assessed the occurrence of AON in a consecutive endoscopic cohort over an 11-year period in a tertiary university centre. To the best of our knowledge, only a few case reports and case series describing AON are available, and the prevalence of this condition is still unknown.

Our study showed that $\mathrm{AON}$ is a very rare condition with a prevalence of $0.06 \%$. Retrospective reports published more than twenty years ago reported an incidence that varies between $0.01 \%$ and $0.28 \%$ [2-4]; these data are quite similar compared to our report, further indicating the rare occurrence of AON.

The current study showed some interesting data. First, in our AON cohort, two patients presented a diagnosis of ZES. To our knowledge, this is the first time that AON has been reported as the first presentation of ZES; this represented a very interesting association, suggesting the possibility that some factors (i.e., acid hypersecretion) might contribute to the chemical and/or ischaemic injury of AON. Erosive oesophagitis has been frequently reported in patients with ZES; in a study by Hirschowitz et al., erosive oesophagitis was reported in $70 \%$ of ZES patients, with more than half of those patients having severe oesophagitis and $40 \%$ with complicated lesions (stricture, ulcer, or Barrett's) [10]. On the other hand, an old report by Moreto et al. cited a single case of AON diagnosed after a surgical intervention of gastrinoma but unfortunately without reporting any additional patient data [3]. Although it is possible to speculate that hyperacidity might play an important role in the development of AON in these patients, it is possible that other specific triggers may act as concomitant mucosal injuries.

Second, we observed that one patient experienced an AON reoccurrence three weeks after the first event. This patient was affected by chronic ischaemic heart disease, hypertension and pneumonia and was subsequently diagnosed with ZES. AON reoccurrence is a rare event that has rarely been observed [11,12]. To our knowledge, only two other cases with AON relapse have been reported. Tanaka et al. reported the case of a male patient with multiple comorbidities (diabetes mellitus, hypertension, hyperlipidaemia, and angina pectoris) with a reoccurrence after approximately 5 months from the first episode [11], and Ramos et al. described a patient who developed a new AON after 4 months [12]. Even if recurrence is rare, it represents an important event to consider in this setting.

Third, we reported a patient with AON during an elective UGE performed for persistent vomiting and diarrhoea. This is a quite unusual clinical presentation since the majority of patients received a diagnosis of AON during an emergency UGE performed for gastrointestinal bleeding. However, in a recent case series, the case of a patient who incidentally received a diagnosis of AON during the endoscopic placement of a naso-gastrojejunal tube was reported [13], and in a previous report, an asymptomatic $\mathrm{AON}$ patient diagnosed during a percutaneous gastrostomy tube placement was described [5]. These atypical clinical presentations substantiated the hypothesis that AON might have a subclinical presentation, likely due to the short duration of the ischaemic/chemical damage that promoted spontaneous mucosal healing; on the other hand, it is possible that an early diagnosis has as counterpart a vague clinical scenario.

According to previous reports, our data show that AON mainly affected elderly male patients. We found that three-quarters of patients were male with a median age of 75 years, similar to other reports where men are four times more commonly affected than women, with a peak of incidence in the sixth or seventh decade of life $[5,6]$. In addition, we confirmed that AON patients have multiple chronic and overlapping acute comorbidities, presenting in the majority of cases with upper gastrointestinal bleeding. However, even if gastrointestinal bleeding (i.e., haematemesis and melena) is the indication to perform UGE in more than $80 \%$ of AON patients, haemodynamic instability was observed only in a few patients.

Regarding the endoscopic findings, we reported that $\mathrm{AON}$ involved the entire length of oesophagus in almost half of AON patients, mostly with concomitant duodenal findings.

Even if AON more frequently affected the distal one-third and the distal two-thirds of the oesophagus, Lamers et al. also reported panoesophageal involvement in a remarkable number of AON patients (three out of five) [13]. Similar to what has been previously reported, the extent of 
oesophageal involvement seemed to be related to the duodenal disease, with almost all patients with panoesophageal injury having a duodenal injury as ulcer and bulb necrosis. This phenomenon might be likely explained by the common blood supply from the celiac axis branches to the oesophagus and duodenum. The typical relative sparing of gastric mucosa might be explained by the different response to the acid insult, since compared to gastric mucosa, oesophageal and duodenal mucosa presented a slower healing process. In addition, duodenal lesions may result in gastric outlet obstruction that, in turn, potentiates the development of mucosal necrosis of the distal oesophagus [1,14].

Oesophageal perforation is the most serious AON complication, generally occurring in less than $7 \%$ of patients [5,6]; however, in our AON cohort, no case of perforation has been reported. On the other hand, we documented stenosis as a complication of AON in a patient with involvement of the distal two-thirds of the oesophagus. We found a prevalence of approximately $6 \%$, which is quite similar to other cohorts in which the reported frequency of oesophageal stenosis has been reported in $10 \%$ of patients $[5,6]$.

Then, we found a mortality rate of $50 \%$ with no patients who died as a direct consequence of AON. Even if no patient died from AON, the overall mortality seems slightly higher compared to previous studies: Augusto et al. showed a mortality rate of $34.5 \%$, and none was a direct consequence of AON [4], whereas Gurvits et al. reported a 5.7\% mortality rate due to AON and an overall mortality rate of $31.8 \%$ [4,5]. In a more recent study, the mortality rate was $12.5 \%$ and unrelated to AON [14]. Even if the specific AON mortality rate remained low, these overall mortality proportions might reflect the clinical severity of included patients in the specific cohort.

We are aware of some limitations of this study. The main limitation is the retrospective nature of the data collection. In addition, oesophageal biopsies were not always available; however, the diagnosis of $\mathrm{AON}$ is endoscopic, and oesophageal biopsies are supportive but not required to make the proper diagnosis. This AON cohort has been collected in a single tertiary university centre, which might affect the generalisability of the study's results.

\section{Conclusions}

In conclusion, $\mathrm{AON}$ is a rare cause of gastrointestinal bleeding diagnosed mainly during emergency UGE, but it can diagnosed during elective endoscopy. Beyond the well-known association between AON and elderly patients with multiple comorbidities, our study showed that ZES might manifest with this critical presentation, and endoscopists must be aware of this evidence.

Author Contributions: Conceptualization, A.B.; Data curation, O.D., C.M. and E.G.; Methodology, O.D. and A.B.; Supervision, R.M., C.V.D., D.G.E. and A.B.; Validation, O.D., C.M., R.M., E.G., C.V.D., D.G.E. and A.B.; Writing-original draft, O.D., C.M. and E.G.; Writing—review and editing, R.M., C.V.D., D.G.E. and A.B.

Conflicts of Interest: The authors declare no conflict of interest.

\section{References}

1. Gurvits, G.E. Black esophagus: Acute esophageal necrosis syndrome. World J. Gastroenterol. 2010, 16, 3219-3225. [CrossRef] [PubMed]

2. Lacy, B.E.; Toor, A.; Bensen, S.P.; Rothstein, R.I.; Maheshwari, Y. Acute esophageal necrosis: Report of two cases and a review of the literature. Gastrointest. Endosc. 1999, 49, 527-532. [CrossRef]

3. Moretó, M.; Ojembarrena, E.; Zaballa, M.; Tánago, J.G.; Ibánez, S. Idiopathic acute esophageal necrosis: Not necessarily a terminal event. Endoscopy 1993, 25, 534-538. [CrossRef] [PubMed]

4. Augusto, F.; Fernandes, V.; Cremers, M.I.; Oliveira, A.P.; Lobato, C.; Alves, A.L.; Pinho, C.; de Freitas, J. Acute necrotizing esophagitis: A large retrospective case series. Endoscopy 2004, 36, 411-415. [CrossRef] [PubMed]

5. Gurvits, G.E.; Shapsis, A.; Lau, N.; Gualtieri, N.; Robilotti, J.G. Acute esophageal necrosis: A rare syndrome. J. Gastroenterol. 2007, 42, 29-38. [CrossRef] [PubMed]

6. Abdullah, H.M.; Ullah, W.; Abdallah, M.; Khan, U.; Hurairah, A.; Atiq, M. Clinical presentations, management, and outcomes of acute esophageal necrosis: A systemic review. Expert Rev. Gastroenterol. Hepatol. 2019, 13, 507-514. [CrossRef] [PubMed] 
7. Jessurun, J.; Cui, I.; Aristi-Urista, G. Acute gangrenous esophageal necrosis black esophagus. A rare form of injury with specific histologic features and diverse clinical associations with a common pathogenesis. Hum. Pathol. 2019, 87, 44-50. [CrossRef] [PubMed]

8. Charlson, M.E.; Pompei, P.; Ales, K.L.; MacKenzie, C.R. A new method of classifying prognostic comorbidity in longitudinal studies: Development and validation. J. Chronic Dis. 1987, 40, 373-383. [CrossRef]

9. World Health Organization. Nutritional Anaemias. Report of a WHO Scientific Group; Technical Report Series no. 405; World Health Organization: Geneva, Switzerland, 1968.

10. Hirschowitz, B.I.; Simmons, J.L.; Johnson, L.F.; Mohnen, J. Risk factors for esophagitis in extreme acid hypersecretors with and without Zollinger-Ellison syndrome. Clin. Gastroenterol. Hepatol. 2004, 2, 220-229. [CrossRef]

11. Tanaka, K.; Toyoda, H.; Hamada, Y.; Aoki, M.; Kosaka, R.; Noda, T.; Katsurahara, M.; Nakamura, M.; Ninomiya, K.; Inoue, H.; et al. A relapse case of acute necrotizing esophagitis. Endoscopy 2007, 39, E305, . [CrossRef]

12. Ramos, R.; Mascarenhas, J.; Duarte, P.; Vicente, C.; Casteleiro, C. Acute esophageal necrosis: A retrospective case series. Rev. Esp. Enferm. Dig. 2008, 100, 583-585. [PubMed]

13. Lamers, C.R.; Mares, W.G.N.; Bac, D.J. Black esophagus: A case series and literature review of acute esophageal necrosis. Scand. J. Gastroenterol. 2018, 53, 1421-1424. [CrossRef] [PubMed]

14. Gurvits, G.E.; Cherian, K.; Shami, M.N.; Korabathina, R.; El-Nader, E.M.; Rayapudi, K.; Gandolfo, F.J.; Alshumrany, M.; Patel, H.; Chowdhury, D.N.; et al. Black esophagus: New insights and multicenter international experience in 2014. Dig. Dis. Sci. 2015, 60, 444-453. [CrossRef] [PubMed]

(C) 2019 by the authors. Licensee MDPI, Basel, Switzerland. This article is an open access article distributed under the terms and conditions of the Creative Commons Attribution (CC BY) license (http://creativecommons.org/licenses/by/4.0/). 